Dhaka Univ. J. Biol. Sci. 31(1): 159-168, 2022 (January) DOI: https://doi.org/10.3329/dujbs.v31i1.57924

\title{
INTEGRATED MANAGEMENT OF SEED BORNE PATHOGENIC FUNGI OF BRRI 29 RICE VARIETY
}

\author{
Pranami Chowdhury ${ }^{1}$, Shamim Shams ${ }^{*}$, Hasna Hena Begum ${ }^{2}$ \\ AND MD. ABUl BASHAR \\ Department of Botany, University of Dhaka, Dhaka-1000, Bangladesh
}

Key words: Integrated management, Pathogenic fungi, BRRI 29 rice variety, Bangladesh

\begin{abstract}
A pot experiment was conducted with the single and combined doses of fungicides, plant extracts and antagonist for the management of nine rice pathogens. A total of 13 treatments including controls with or without inocula of the pathogen were tested. Amongst all the treatments only T6 (Bavistin + Azadirachta indica + Trichoderma harzianum) showed highest percentage of seed germination and seedling vigor index of seeds inoculated with Alternaria alternata , Aspergillus flavus, Curvularia lunata and Pestalotiopsis guepinii. Next to T6, T10 (Bavistin + Tall + Azadirachta indica + Citrus medica) showed promising result against Drechslera oryzae, Fusarium moniliforme, Microdochium oryzae and Sarocladium oryzae. T3 treatment (Azadirachta indica) showed highest percentage of seed germination and seedling vigor index in case of seeds inoculated with Fusarium solani. Amongst all treatments the integrated use of Bavistin, A. indica and T. harzianum showed the better performance for growth reduction of test pathogens and increased germination of seeds.
\end{abstract}

\section{Introduction}

Rice is the staple food of Bangladesh and there are many constraints responsible for low yield of rice in Bangladesh. The extremely seed borne pathogens viz. Bipolaris oryzae (Breda de Haan) Shoem. Fusarium moniliforme Sheldon, Pyricularia oryzae Cavara, Rhizoctonia solani Kuhn, Sarocladium oryzae (Sawada) W. Gams. and D. Hawks, Sclerotium oryzae (Catt.) R.A. Krause and R.K. Webster, Microdochium oryzae (Hashloka and Yokogi) Sam. and Hal., Curvularia lunata (Wakker) Boedijn etc. are associated with seed infection of rice causes yield reduction, quality deterioration and germination failure ${ }^{(1-3)}$. These diseases are very common in many parts of South East Asia and considerable losses in rice production. Grain spotting or discoloration causes both quantitative and qualitative losses in rice ${ }^{(4)}$. In Bangladesh, 43 diseases are known to occur on the rice crop and among these 36 are seed borne, of which 14 are of major importance(5). Of all the seed borne diseases of rice, 22 are caused by fungi ${ }^{6}$. Approximately 2.5 million tons of rice worth more than Tk.12000 million is lost annually due to diseases caused by seed borne pathogens ${ }^{(7)}$.

*Author for correspondence: <prof.shamsi@gmail.com>. ${ }^{1 B o t a n y ~ D e p a r t m e n t, ~ G o v t . ~ T i t u m i r ~}$ College, Dhaka, Bangladesh. '2Department of Botany, Jagannath University, Dhaka-1100, Bangladesh. 
Fungal pathogens have becoming an increasing problem for rice cultivation in Bangladesh. Relative humidity and high temperature during plant growth favor development of seed borne disease. This disease is a major constraint in obtaining potential yield from the modern rice varieties. Therefore emphasis should be paid on other alternative management options. Chemical control is very common for controlling of the disease but it causes hazard to human health and environment. However, to keep the environment chemical-free, dependence on chemicals should be reduced as far as possible.

Lots of researches have been done on rice grain pathogens and its management ${ }^{(8-18)}$. But information on integrated management of rice seed borne pathogens is insufficient ${ }^{(19-24)}$. By keeping in view the above mentioned facts, an integrated programme was aimed to control rice seed borne pathogens. The present study was undertaken to screen out some fungicides, plant extracts and antagonist for the integrated management of rice pathogens and their impact on yield and yield contributing factors of rice.

\section{Materials and Methods}

The experiment was conducted in a completely randomized design with three replications in the earthen pot of Botanical garden, University of Dhaka, to assess the single and combined doses of fungicides, plant extracts and antagonist for the management of nine rice pathogens. A total of 13 treatments including controls with or without inocula of the pathogens were tested. The experiment was designed in a randomized block design with 3 replications. Pot soil was prepared by mixing sandy loam soil and decomposed organic fertilizer at the ratio $4: 1$. The plastic pots $(20 \mathrm{~cm}$ diameter) were filled with $2 \mathrm{~kg}$ soil which was treated with formalin. A high yielding susceptible rice variety BRRI 29 was selected for this study(25).

The treatments and their combinations were $: \mathrm{T} 1=$ Bavistin, $\mathrm{T} 2=$ Tall, $\mathrm{T} 3=$ Azadirachta indica, $\mathrm{T} 4=$ Citrus medica $\mathrm{T} 5=$ Trichoderma harzianum, $\mathrm{T} 6=$ Bavistin + Azadirachta indica + Trichoderma harzianum $\mathrm{T} 7=$ Bavistin + Citrus medica + Trichoderma harzianum, $\mathrm{T} 8=\mathrm{Tall}+$ Azadirachta indica + Trichoderma harzianum, $\mathrm{T} 9=$ Tall + Citrus medica + Trichoderma harzianum, $\mathrm{T} 10=$ Bavistin + Tall + Azadirachta indica + Citrus medica, $\mathrm{T} 11=$ Bavistin + Tall + Azadirachta indica + Citrus medica + Trichoderma harzianum , T12 = Control (with inocula), $\mathrm{T} 13$ = Control (without inocula). Seeds were suspended with the inocula suspension of test pathogens for 1 hour and treated with the above mentioned treatments for 2 hours. Then the seeds were sowing in plastic pots. Treatments were applied at 10 days intervals. Data were recorded after 15, 20, 25 days of germination. Twenty five days old seedlings of BRRI 29 variety were uprooted carefully to avoid root injury. The shoot and root length were taken separately against all tested pathogens. The percentage of germination and mortality was also recorded. 
The experiment was performed twice. Data on different parameters were analyzed following computer package MSTAT-C and means were compared using Duncans Multiple Range Test (DMRT).The data were collected and evaluated by analysis of variance (ANOVA) by using STAR statistical program.

\section{Results and Discussion}

Effects of different treatments with fungicides, leaf extracts and antagonist on seed quality parameters of BRRI 29 rice variety against Alternaria alternata, Aspergillus flavus, Curvularia lunata, Drechslera oryzae, Fusarium moniliforme, Fusarium solani, Microdochium oryzae, Pestalotiopsis guepinii and Sarocladium oryzae are presented in Tables 1-3 and Fig 1.

Combined effect of fungicides, plant extracts and antagonist on seed quality parameters of BRRI 29 rice variety against Alternaria alternata, Aspergillus flavus and Curvularia lunata

Due to combined effect of different treatments with fungicides, leaf extracts and antagonist on seed quality parameters of BRRI 29 rice variety against A. alternata, $A$. flavus and C. lunata,T6 (Bavistin $+A$. indica $+T$. harzianum ) treatment showed highest percentage of seed germination (87, 83 and 83\%) and seedling vigor index (1496.4, 1517 and 1596.92), respectively. Amongst 13 treatments T10 (Bavistin + Tall $+A$. indica $+C$. medica) was next to T6, and T11 (Bavistin + Tall + A. indica + C. medica+ T. harzianum) showed promising result, respectively (Table 1 ). In case of root length, shoot length and mortality of seedlings, significant differences were observed due to different treatments against A. alternata, A. flavus and C. lunata (Table 1).

Combined effect of fungicides, plant extracts and antagonist on seed quality parameters of BRRI 29 rice variety against Drechslera oryzae, Fusarium moniliforme and Fusarium solani

Inoculated seeds with $D$. oryzae and F. moniliforme showed highest per cent (74 and75\%) of seed germination and seedling vigor index (1281.6 and 1144 ), respectively due to combined effect of T10 (Bavistin+Tall $+A$. indica $+C$. medica) treatment. Next to T10, T11 (Bavistin+Tall $+A$. indica $+C$. medica $+T$. harzianum) showed better result which was followed by T6 (Bavistin $+A$. indica $+T$. harzianum). Seeds inoculated with $F$. solani showed highest per cent of seed germination $(81 \%)$ and seedling vigor index (1360.8) due to T3 (A. indica) treatment followed by T8 (Tall $+A$. indica $+T$. harzianum) and T6 (Bavistin $+A$. indica+T. harzianum) treatments. Different treatments did not make any significant difference in root and shoot lengths and also mortality of seedlings against $D$. oryzae, $F$. moniliforme and F. solani (Table 2). 
Combined effect of fungicides, plant extracts and antagonist on seed quality parameters of BRRI 29 rice variety against Microdochium oryzae, Pestalotiopsis guepinii and Sarocladium oryzae

Seeds inoculated with $M$. oryzae and $S$. oryzae showed highest per cent of germination due to combined effect of T10 (Bavistin+Tall+Azadirachta indica $+C$. medica ) which showed highest per cent (82 and $84 \%$ ) of seed grrmination and seedling vigor index (1590.8 and1546.4), respectively amongst 13 treatments. Next to T10, T11 (Bavistin+Tall + A.indica + C. medica + T. harzianum) and T6 (Bavistin + A. indica + T.harzianum) showed promising result in both the cases. Seeds inoculated with P. guepinii showed highest per cent ( $85 \%$ ) germination and seedling vigor index (1487.5) due to combined effect of T6 (Bavistin $+A$. indica+T. harzianum) treatment followed by T10 and T11 treatments, respectively (Table 3). There was no significant difference in the length of root and shoot, and mortality of seedlings due to different treatments against M.oryzae and S. oryzae. However, slight difference was noticed in case of the lengths of root and shoot along with the mortality of seedlings against $P$. guepinii due to different treatments (Table 3).

The results of this investigation showed similarity with the findings of Hossain and $\mathrm{Mia}^{(19)}$, Ashrafuzzaman et al.(20), Islam and Monjil(21), Gohel and Chauhan ${ }^{(22)}$ and Balgade and Gaikwad(23). Hossain and Mia ${ }^{(19)}$ observed two foliar sprays with Aimcozim, Bavistin, Shincar and Tilt at $0.1 \%$ and two top dressing of MP with $40 \mathrm{~kg}$ ha caused significant reduction of tiller infection of sheath blight disease. They also reported that tilt was the best fungicide for controlling the disease. Ashrafuzzaman et al. ${ }^{(20)}$ reported the integrated management of sheath blight of aman rice through different combinations of treatment including controls with or without inocula of the pathogen. Severity increased with the increasing maturity of rice plants under all the treatments. The development was significantly least in plants treated with combined doses. The highest yield of rice was recorded in plants with the combined doses. Islam and Monjil (21) detected complete inhibition of sheath blight pathogen when treated with four indigenous medicinal plant extracts i.e. tulsi, nishinda, thankuni and biskatali and also reported germination failure due to fungal infection.

Islam and Monjil(22) observed number of infected tillers per hill and the lowest was found in seeds treated with propiconazole and biskatali (Polygonum hydropiper) extracts. Another three plants reduced tiller infection compared to control. They also reported highest vigor index in Jute seedlings raised from prewashed seeds treated with garlic and Know in which resulted significant reduction of seed borne fungal population.

Gohel and Chauhan ${ }^{(23)}$ observed the efficacy of fungicides, bio-agent (Pseudomonas flourescens) and botanicals ( neem, tulshi leaves extracts) for the management of rice blast pathogen and then reported the combined use of these reduced the pathogen and 


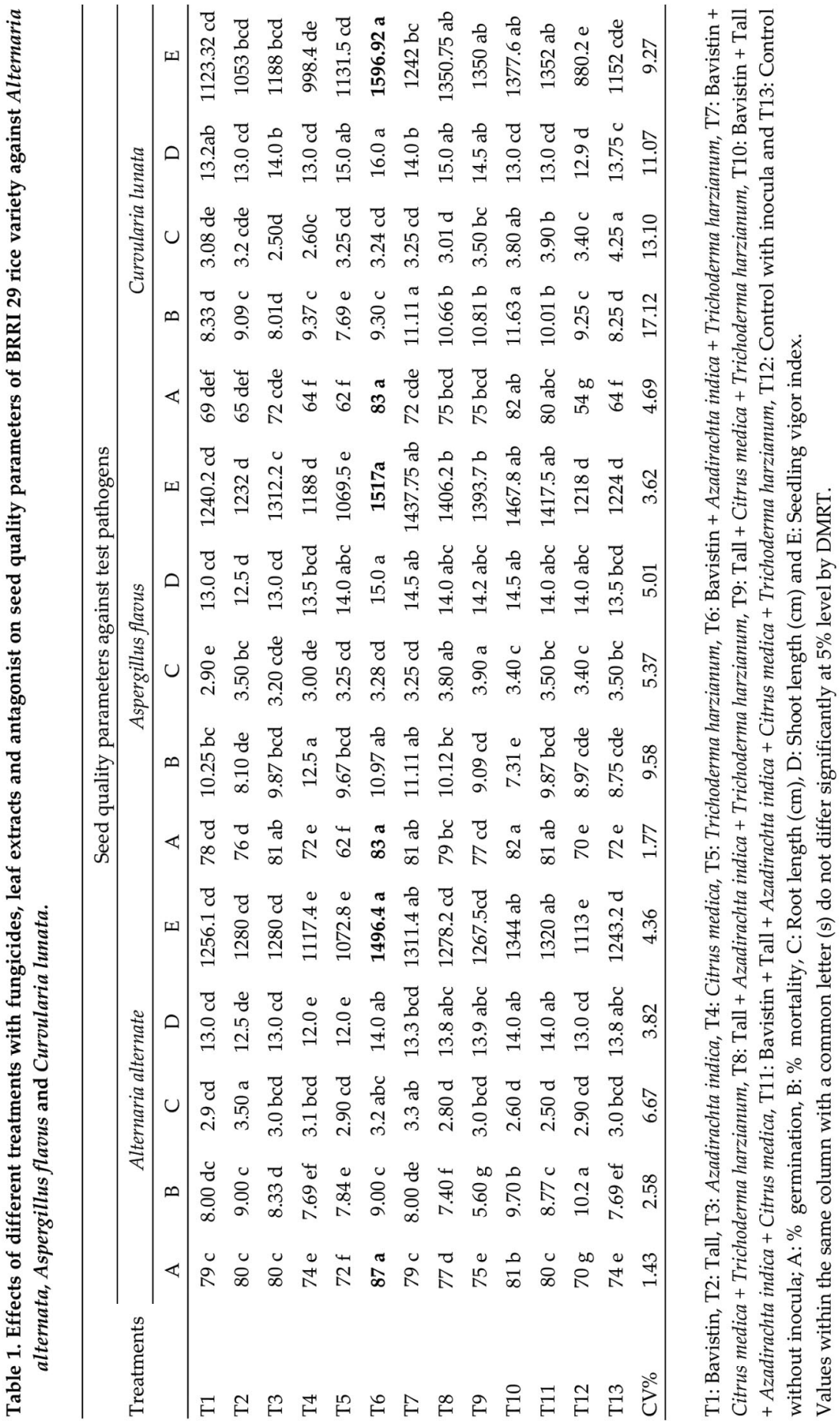




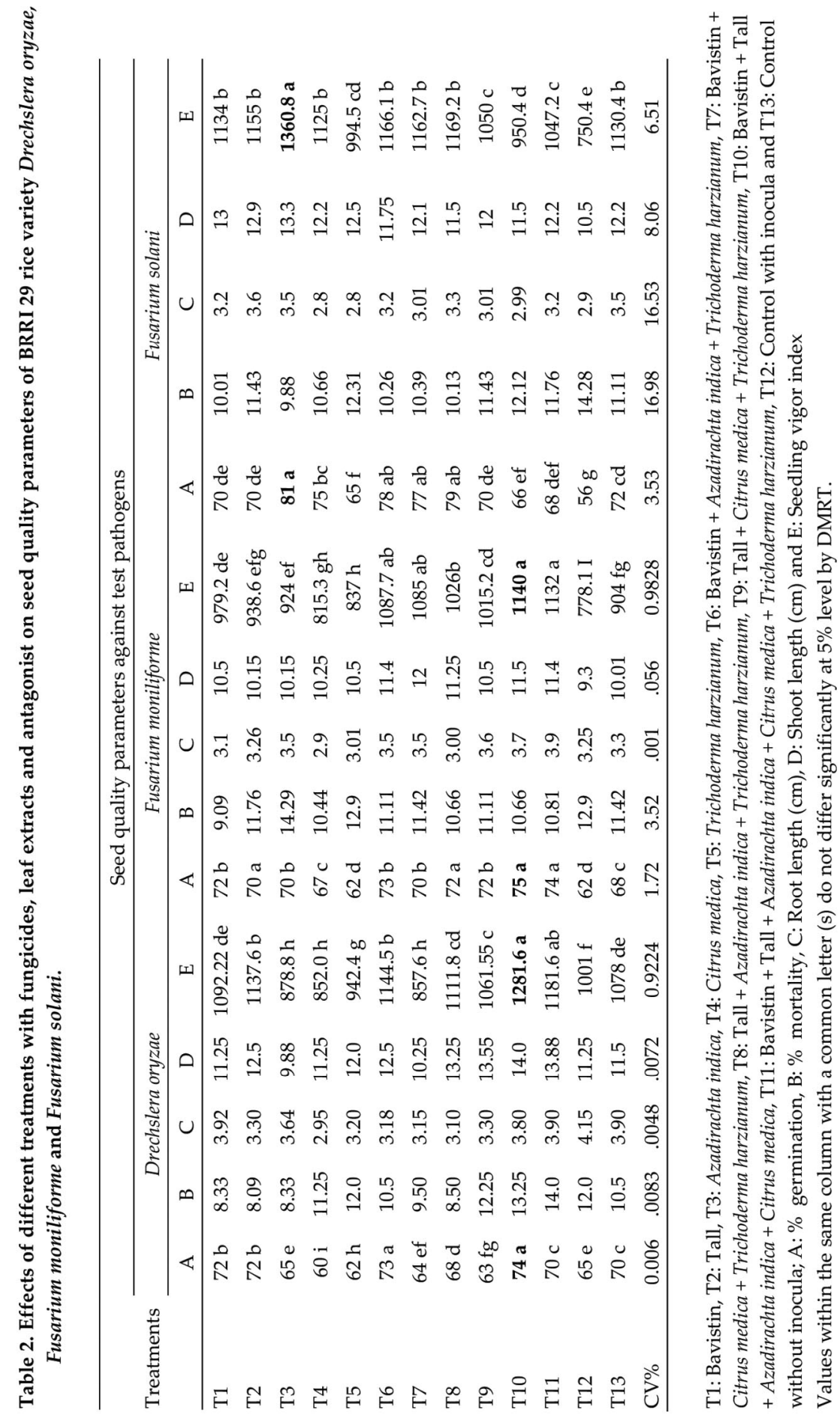




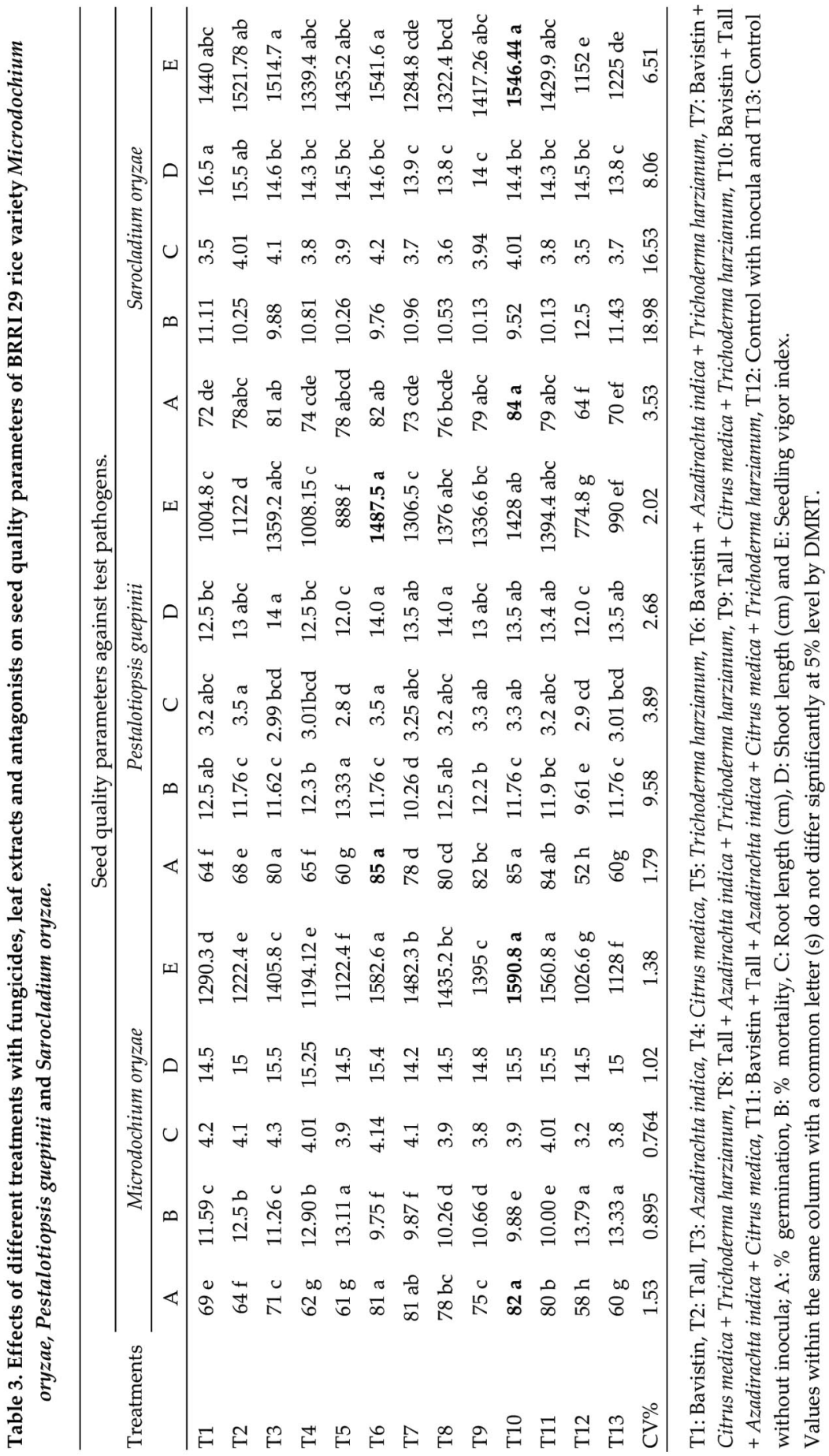



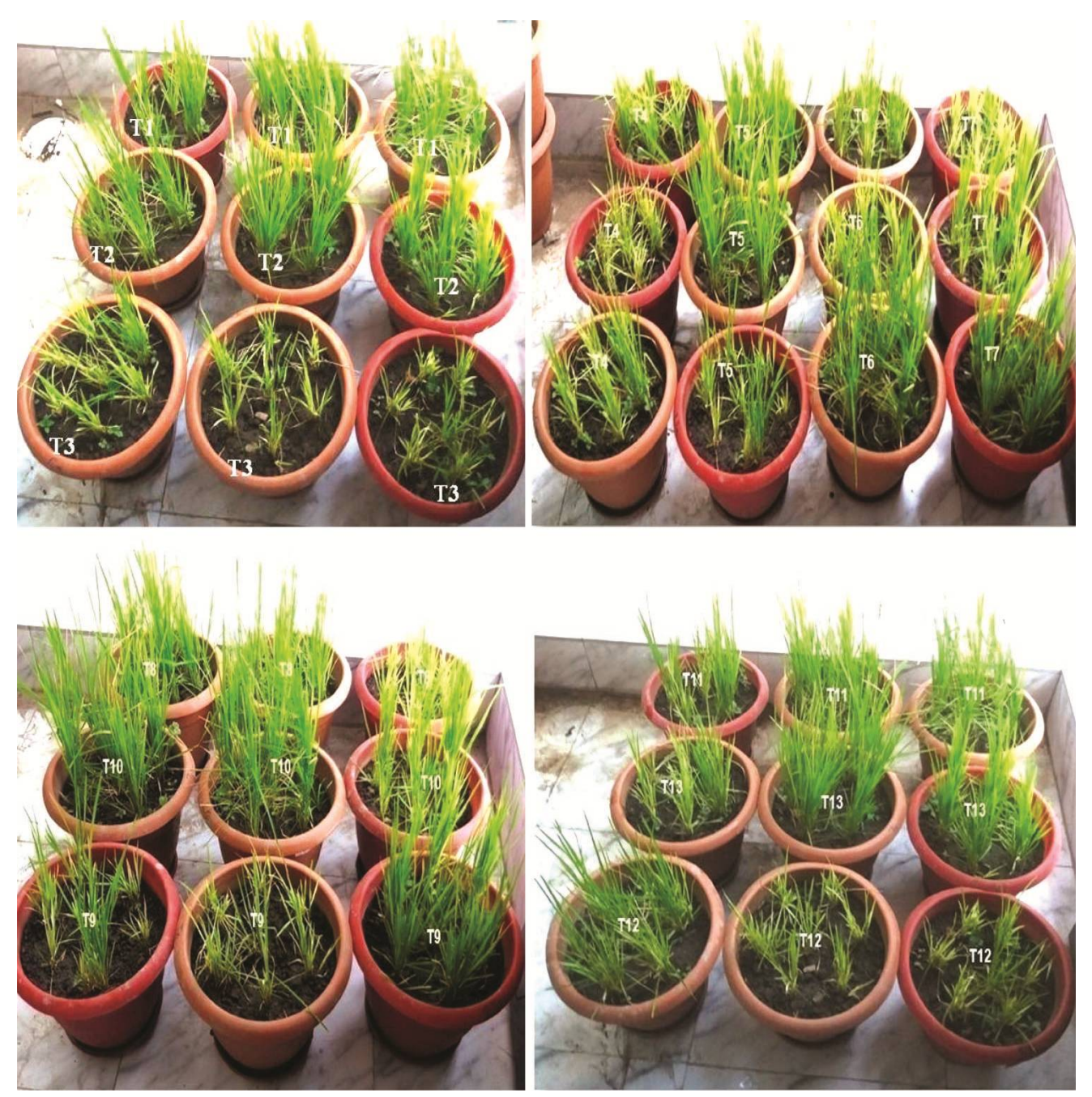

Fig. 1. Combined effects of treatments with fungicides, plant extracts and antagonist.

T1. Bavistin, T2. Tall and T3. Azadirachta indica, T4. Citrus medica, T5. Trichoderma harzianum, T6. Bavistin + Azadirachta indica + Trichoderma harzianum, T7. Bavistin + Citrus medica + Trichoderma harzianum, T8. Tall + Azadirachta indica + Trichoderma harzianum, T9. Tall + Citrus medica + Trichoderma harzianum, T10. Bavistin + Tall + Azadirachta indica + Citrus medica, T11. Bavistin + Tall + Azadirachta indica + Citrus medica + Trichoderma harzianum, T12. Control with inocula, T13. Control without inocula

increased yield parameters. Balgade and Gaikwad(24) observed the integrated management of blast of rice through seed treatment with benomyl $(0,3 \%)$ followed by Pseudomonas fluorescens ( $0.5 \%$ ) and cultural practices (CP) like soil application of rice husk ash (RHA) at sowing on raised beds $(1 \mathrm{~kg} / \mathrm{m} 2)$ with soil application of rice straw (2 tons ha) at transplanting. But highest disease reduction were recorded in the combination of seed treatment and cultural practices with three sprays of propiconazole. 
Almost all the treatments were effective against test pathogens and showed the maximum germination of seedlings in comparison to control. The highest germination and seedling vigor index was recorded in inoculated seeds with A. alternata, A. flavus, $C$. lunata and P. guepinii grown in pots where the integrated doses of Bavistin , A. indica and T. harzianum ('T6) were applied followed by seeds grown in pots amended with the integrated doses of Bavistin, Tall, A. indica and T. harzianum (T10). But in case of inoculated seeds with D. oryzae, F. moniliforme, $M$. oryzae and S. oryzae showed maximum germination due to combined effect of T10 treatment followed by T6 treatment. Only $A$. indica (T3 treatment) treated seeds showed highest germination and seedling vigor index against $F$. solani.

Considering the overall performance of the treatments, the combined use of Bavistin, A. indica and T. harzianum showed better performance for the reduction of test pathogens and increased germination considerably.The present investigation revealed that the integrated treatment T6 (Bavistin $+A$. indica $+T$. harzianum) might be useful for the management of rice pathogens and increasing germination of rice seeds.

\section{Acknowledgement}

The first author gratefully acknowledges to the University Grants Commission, Agargaon, Dhaka, Bangladesh for providing financial assistance to this research work in the form of a research fellowship.

\section{References}

1. Mia MAT, AKM Shahjahan and SA Miah 1979. Microorganism Associated with Spotted and Discolored Rice Grains in Bangladesh. Intl. Rice Res. Newslett. 4(5): 8.

2. Shahjahan AKM, MAT Mia and SA Miah 1988. Rice Grain Spotting and Associated Organisms. Bangladesh J. Plant Pathol. 4(1\&2): 1-7.

3. Haque AHMM, MAH Akhon, MA Islam, KM Khalequzzaman and MA Ali 2007. Study on Seed Health, Germination and Seedling Vigor of Farmers Produced Rice Seeds. Intl. J. Sustain. Crop Prod. 2(5): 34-39.

4. Sharma HL, HS Randhawa, A Kapur and S Singh 1987. Seed Discoloration in Rice, Seed Research and Protect Unit 24(1): 37-41.

5. Ora N, AN Faruq, MT Islam, N Akhtar and MM Rahman 2011. Detection and Identification of Seed Borne Pathogens from Some Cultivated Hybrid Rice Varieties in Bangladesh. Middle-East J. Sci. Res. 10(4): 482-488.

6. Fakir GA 2000. An annotated list of seed borne disease of Bangladesh. Seed Pathology Laboratory. Department of plant pathology, BAU. Mymenshing pp. 41.

7. Fakir GA, I Hossain, MU Ahmed, MK Anam, MN Anam, MN Alam and M Rahman 2003. Effect of ash, chalk powder and neem leaf on the quality of born rice seed stored in gunny bag, motka, plastic drum and tin. Proceeding of review and planning meeting of the Rice Seed Health Improvement Sub-project held at BRRI, Gazipur, Bangladesh during 21-22 April, 2003. pp. 1-37. 
8. Ganguly D 1946. Helminthosporium disease in Bengal. Sci. and Cult. 112: 220-223.

9. Neergaard P 1977. Seed Pathology. A Halsted Press Book. Vol. 1, pp. 180.

10. Ou SH 1985. Rice Diseases. Commonwealth Mycological Institute, Kew, Surrey, England.

11. Archana B and HS Prakash 2013. Survey of seed borne- fungi associated with rice seeds in India. Int. J. Res. Pure Appl. Microbiol. 3(1): 25-29.

12. Farid AKM, Khalequzzaman, N Islam, MK Anam and MT Islam 2002. Effect of fungicides against Bipolaris oryzae of rice under in vitro condition. Pak. J. Plant Pathol 1(1): 4 -7.

13. Shamsi S, AZM Nowsher A Khan, AKM Shahjahan and SA Miah 2003. Fungal species associated with sheaths and grains of sheath rot affected rice varieties from Bangladesh. Bangladesh J. Bot. 32(1): 17-22.

14. Mohana DC, P Prasad, V Vijaykumar and KA Raveesha 2011. Plant extract effect on seed borne pathogenic fungi from seeds of paddy grown in Southern India. Journal of Plant Protection Research 51: 102-106.

15. Yeasmin F, M Ashrafuzzaman and I Hossain 2012. Effects of garlic extract, Allamanda leaf extract and Provax-200 on seed borne fungi of rice. The Agriculturists 10(1): 46-50.

16. Habib A, N Javed, ST Sahi and M Waheed 2012. Detection of seed borne mycoflora of different coarse and fine rice varieties and their management through seed treatments. Pak. J. Phytopathol. 24(2): 133-136.

17. Mansur A, M Hossain, K Hassan and CK Dash 2013. Efficacy of different plant extract on reducing seed borne infection and increasing germination of collected rice seed sample. Universal Journal of Plant Science 1(3): 66-73.

18. Chowdhury P, MA Bashar and S Shamsi 2015. In vitro evaluation of fungicides and plant extracts against pathogenic fungi of two rice varieties. Bangladesh J. Bot. 24(2): 251-259.

19. Hossain M and MAT Mia 2001. Management of sheath blight diseases of rice under farmers field condition. Bangladesh J. Plant Pathol. 17(1-2): 13-16.

20. Ashrafuzzaman M, M Jalaluddin, MI Khalil and I Hossain 2005. Integrated Management of Sheath Blight of Aman Rice. Bangladesh J. of Plant Pathol. 21(1-2): 53-62).

21. Islam MM and MS Monjil 2016. Effect of aqueous extracts of some indigenous medicinal plants on sheath blight of rice. Journal of the Bangladesh Agric. Univ. 14(1): 7-12.

22. Islam MM and MS Monjil 2016. Effect of seed washing either alone or in combination with garlic extract and knowin 50 WP on quality of jute seeds. Asian Journal of Medical and Biological Research 2(2): 318-323.

23. Gohel NM and HL Chouhan 2015. Integrated management of leaf and neck blast disease of rice caused by Pyricularia oryzae. African Journal of Agricultural Research 10(19): 2038-2040.

24. Balgade YS and AP Gaikwad 2019. Integrated management of blast of rice. International Journal of chemical studies (1): 1557-1563.

25. Anonymous 2004. Adhunik Dhaner Chash. 12 th Edn. Bangladesh Rice Research Institute (BRRI). Joydebpur, Bangladesh. 60 p.

(Manuscript received on 13 May, 2021; accepted on 25 November, 2021) 